11. Effect of Blueberry Polyphenols on 3T3-F442A Preadipocyte Differentiation / S. S. Moghe [et al.] // Journal Of Medicinal Food. - 2012. - №15 (5). - P. 448-452.

12. Hypergastrinemia, type 1 gastric carcinoid tumors: diagnosis and management / O. Y. Hung, S. K. Maithel, F. F. Willingham [et al.] // J. Clin. Oncol. - 2011. - V. 29, № 25. - P. 713-715.

13. Green tea polyphenols provide photoprotection, increase microcirculation, and modulate skin properties of women / H. Ulrike [et al.] // The Journal of nutrition. - 2011. - № 141(6). - P.1202-1208.

14. Gurlenko T. The influence of long-term omeprazole-induced hypergastrinemia on water and electrolyte transport in the rat colon / T. Gurlenko, O. Voronina, V. Grishcuk [et al.] // Annales Universitatis Mariae Curie-Sklodowska. - 2006. - Vol. XIX, № 1, 10. - P. 71-73.

15. Inonotus obliquus Protects against Oxidative Stress-Induced Apoptosis and Premature Senescence / J. Seok Yun, J. Woon Pahk, J. Seok Lee [et al.] // Mol Cells. - 2011. - №31. - P. 423-429.

16. Kamon M. Green tea polyphenol(-)-epigallocatechin gallate suppressed the differentiation of murine osteoblast MC3T3-E1 cell / M. Kamon, R. Zhao, K. Sakamoto // Cell Biology International. - 2009. №34(1). - P. 109-116.

17. Mimura T. Studies on biological activities of melanin from marine animals. IV. Influence of squid melanin II on a high molecular glycoprotein level in rat gastric mucosa, and properties of peak I as a gastric mucosal defensive factor / T. Mimura, [et al.] // Chem Pharm Bull. - 1985. - № 33. - P. 2061-2068.

18. Molecular mechanism of black tea polyphenols induced apoptosis in human skin cancer cells: involvement of Bax translocation and mitochondria mediated death cascade / B. Halder [et al.] // Carcinogenesis. - 2008. № 29. - P. 129-138.

19. The gastric epithelial progenitor cell niche and differentiation of the zymogenic (chief) cell lineage / A. J. Bredemeyer [et al.] // Developmental Biology. - 2009. - Vol. 325, Issue 1. - P. 211-224

20. Slobodyanyk N. Pancreatic Enzymes Activity under the Conditions of Acute Stress and Melanin Administration Depending on the Stress Resistance / N. Slobodyanyk, T. Beregova, K. Neporada // Journal of Pharmacy and Pharmacology. - 2015. - № 3. - P. 232-236.

21. Watson R.R. Polyphenols in Human Health and Disease / R. R. Watson, V. R. Preedy, S. Zibadi // Academic Press, 2013. - P. 1360-1362.

Воронина Елена, Береговая Татьяна, Дзержинский Николай. Электронно-микроскопическое исследование слизистой оболочки фундального отдела желудка крыс при действии меланина на фоне гипергастринемии. С помощью электронно-микроскопического метода исследовались изменения в слизистой оболочке фундального отдела желудка крыс при действии меланина на фоне гипергастринемии. Исследования проводили на 30 самцах крыс. Материалом служили участки дна желудка: после 28-дневного введения омпепразола, после одновременного 28-дневного введения омперазола и меланина и контрольных животных. Показано, что при гипергастринемии во всех слоях слизистой происходят изменения, свидетельствующие о передракових процессах. В эпителии отмечается атипия клеток, разрушение их белок-синтезирующего аппарата, отсутствие дифференциации эндокриноцитов. Введение меланина нивелирует трофическое действие избыточного уровня гастрина на эпителиоциты слизистой оболочки желудка крыс, о чем свидетельствует появление дифференцированных эндокриноцитов, восстановление секреторной функции эпителиоцитов и отсутствие атипичных клеток.

Ключевые слова: гипергастринемия, слизистая оболочка желудка, малигнизация, меланин.

Voronina Olena, Beregova Tetyana, Dzerzhinsky Mykola. Ultrastructural Effects in Fundus Mucosa of Rats with Hypergastrinemia under the Influence of Exogenous Melanin. Using electron microscopy, ultrastructural changes in fundus mucosa of rats suffering from hypergastrinemia following melanin treatment were investigated. Studies were conducted using 30 male rats. Selected areas of stomach fundus were analyzed in rats which received: 28 days of single omeprazole injections, 28 days of combined omeprazole and melanin injections, and control animals. Hypergastrinemia induced ultrastructural changes were observed in all mucosal layers, indicating clear malignization. Atypic epithelial cells, destruction of their protein-synthesizing apparatus, lack of endocrine cells differentiation were found. Introduction of melanin was shown to eliminate the trophic effect of excessive gastrin levels to the epithelial cells of gastric mucosa in rats, as evidenced by the appearance of differentiated endocrine cells, restoration of secretory function of epithelial cells and lack of atypical cells.

Key worlds: hypergastrinemia, fundus mucosa of stomach, malignization, melanin.

Стаття надійшла до редколегії 22.09.2016 р. 


\section{Вплив мікрохвильового випромінювання на стан антиоксидантної системи в тканинах перепелиних ембріонів та добового молодняку}

У роботі на моделі перепелиного ембріона продемонстровано достовірний оксидативний ефект мікрохвильового випромінювання, який проявлявся у вираженому зростанні рівня перекисного окиснення ліпідів і зниженні активності ключових ферментів антиоксидантної системи живих клітин.

Ключові слова: мікрохвильове випромінювання, мобільний телефон, ембріогенез, оксидативний стрес, антиоксиданти.

Постановка наукової проблеми та її значення. Неіонізуюче електромагнітне випромінювання (EMB), зокрема радіодіапазону, - невід'ємний фактор зовнішнього середовища в оточенні людини. Проте впродовж останніх десятиліть рівень цього фактора на планеті, особливо в індустріально розвинених країнах, драматично зріс. Так, рівень фонового радіовипромінювання в житлових приміщеннях Німеччини в 1985-2005 pp. зріс у 5000 разів [1], що, вочевидь, зумовлено розвитком бездротових технологій, передусім мобільного зв’ язку. На кінець 2015 р., за оцінками International Telecommunication Union, кількість активних користувачів мобільних телефонів перевищила 7 млрд [2]. Цей факт викликає закономірну насторогу щодо ризиків для здоров’ я людини.

Епідеміологічні дослідження останніх років підтвердили, що довготривале та інтенсивне використання мобільного зв'язку може спричиняти суттєві ризики для здоров'я людини внаслідок надмірного радіоопромінення. Так, виявлено достовірне зростання ризиків розвитку гліом, менінгіом, неврином слухового нерва, пухлин білявушних слинних залоз, головного болю, відчуття фізичного дискомфорту в користувачів мобільного зв'язку при багаторічному (5-10 років) інтенсивному користуванні мобільними телефонами [3].

Аналіз сучасних даних щодо біологічної дії низькоінтенсивного РЧВ приводить до висновку, що цей фізичний агент - потужний оксидативний стрес-фактор для живої клітини. Оксидативні ефекти РЧВ можуть бути пов'язані зі змінами у функціонуванні ключових АФК-генеруючих систем клітин, уключаючи ЕТЛ мітохондрій і нефагоцитарні НАДН-оксидази; безпосереднім впливом на молекули води; конформативними змінами важливих макромолекул тощо [4]. Значний патогенний потенціал АФК та їх участь у регуляції клітинного метаболізму пояснює широкий спектр біологічних ефектів низькоінтенсивного РЧВ, уключаючи як онкологічні, так і неонкологічні патології.

Мета роботи - дослідження впливу МХB на стан антиоксидантної системи в тканинах перепелиних ембріонів та добового молодняку.

Матеріали та методи дослідження. У роботі використано ембріони перепела японського (Japanese quail). Для експериментів формувавли по дві групи свіжих інкубаційних яєць (дослідну й контрольну, по 8-10 шт. у кожній), які інкубували in ovo. Інкубацію здійснювали за оптимальних умов для розвитку перепелиного ембріона: $38,3 \pm 0,2{ }^{\circ} \mathrm{C}$, відносна вологість - $60 \%$. Яйця розміщували в горизонтальних лотках і перевертали тричі на день. Перша група слугувала інтактним контролем, друга піддавалася дії мікрохвильового випромінювання (MXB) стандарту GSM 900 МГц.

За джерело MXB використовували 3G USB-модем Huawei E173 та комерційну модель мобільного телефона Nokia 3120, які активізували комп’ютерною програмою автодозвону в режимі 48 с «увімкнуто», 12 с - «вимкнуто». У стані «увімкнуто» система випромінювала MXB стандарту GSM

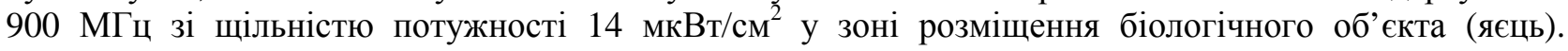
Інтенсивність МХВ оцінювали вимірювачем електромагнітного випромінювання радіочастотного діапазону (RF Field Strength Meter, Alfalab Inc., USA).

Ембріони першої дослідної групи піддавали 158-годинному опроміненню. Цей час уключав 120 год (п’ять діб) опромінення ембріонів in ovo за кімнатної температури перед закладкою на інкубацію та 38 год від закладки в інкубатор. Інші дослідні групи піддавалися 120 год (п’ять діб); 240 год (10 діб) або 336 год (добові перепели) опромінення після початку інкубації (залежно від строку аналізу). Дослідні й контрольні групи впродовж усього експерименту екрановано кількома шарами алюмінієвої фольги й розміщено на відстані 10 см одна від одної. Фонове радіовипромінювання в лабораторії становило

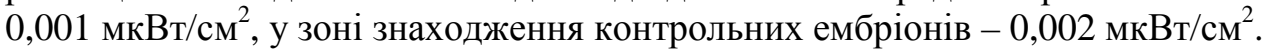

(C) Цибулін О., 2016 
Рівень пероксидів ліпідів у гомогенатах тканин ембріонів визначали в тесті з тіобарбітуровою кислотою в присутності іонів $\mathrm{Fe}^{2+}$ [5]. Крім того, розглядали активність ферментів антиоксидантного захисту - супероксиддисмутази (СОД) каталази та церулоплазміну [6-8].

Виклад основного матеріалу й обгрунтування отриманих результатів досліджень. Мікрохвильове випромінювання викликало оксидативний стрес в ембріональних клітинах та клітинах добових перепелів. Зокрема, рівень ПОЛ (рис. 1) у тканинах 38-годинних ембріонів був вірогідно ( $<0,05)$ вищим на 37,52 \% у дослідній групі, порівняно з контролем. У тканинах 5-добових ембріонів дослідної групи вміст ТБК-реагуючих сполук також вищий на 15,66 \%, порівняно з контролем. Подібну тенденцію простежено й у мозку та печінці 10-добових ембріонів дослідної групи. Проте в серці ембріонів дослідної групи вміст ТБК-реагуючих сполук залишався вірогідно $(p<0,05)$ нижчим на 38,49 \%, порівняно з контролем. У добових перепелів дослідної групи рівень ПОЛ залишався вірогідно $(\mathrm{p}<0,05)$ вищим лише в печінці, а в мозку й серці цей показник перебував на рівні контрольної групи.

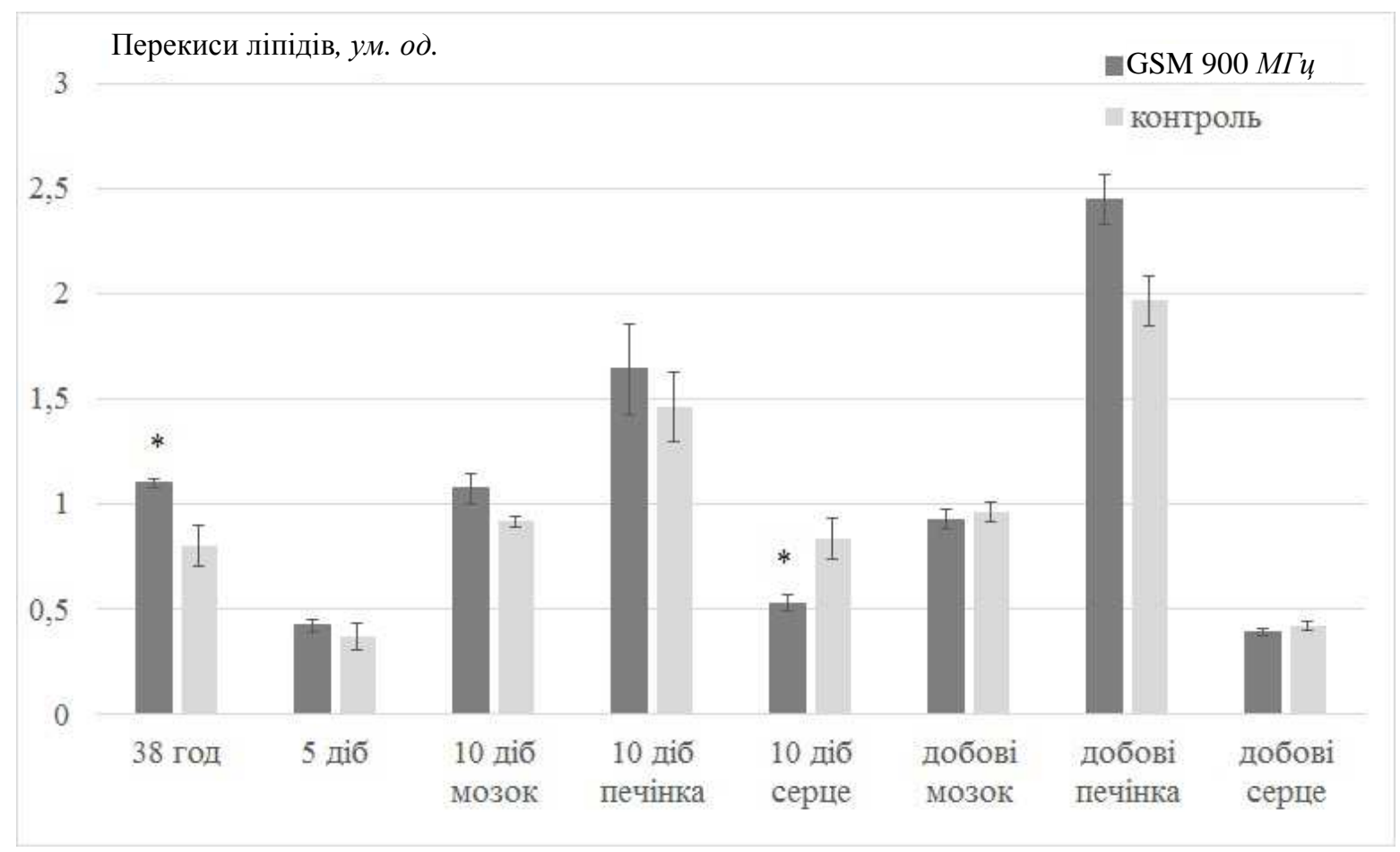

Рис. 1. Вплив опромінення перепелиних яєць мікрохвильовим випромінюванням стандарту GSM 900 MГи на рівень ТБК реагуючих перекисних ліпідних сполук у гомогенаті тканин перепелиних ембріонів та добових перепелів: $n=7 ; M \pm m$, *p<0,05, порівняно з контролем

Активність каталази (рис. 2) у тканинах 38-годинних ембріонів дослідної групи була вірогідно ( $<<0,01$ ) нижчою на 78,64 \%, порівняно з контролем. У гомогенаті тканин 5-добових ембріонів дослідної групи активність каталази також вірогідно $(\mathrm{p}<0,05)$ нижча на $37,19 \%$, порівняно 3 контролем. У мозку 10-добових ембріонів дослідної групи активність каталази була вірогідно (p<0,01) вищою на 73,48 \%, порівняно з контролем, а в печінці та серці цей показник нижчий за контрольні на $17,53 \%(\mathrm{p}<0,05)$ та 31,55 \% відповідно. У добових перепелів зниження активності каталази простежено в печінці.

Аналіз активності СОД (рис. 3) виявив зниження на 17,27 \% цього показника в гомогенаті тканин 38-годинних ембріонів дослідної групи, порівняно з контролем. Натомість у 5-добових ембріонів активність СОД при мікрохвильовому опроміненні вірогідно (р<0,001) вища на 39,83 \%, порівняно 3 контролем. У печінці та серці 10-добових ембріонів дослідної групи активність СОД була нижчою за показники контрольної групи на $12,81 \%$ та $14,53 \%$ відповідно, а в мозку різниця між дослідною й контрольною групами практично відсутня. Активність СОД у тканинах добових перепелів у мозку птиці дослідної групи була вірогідно (p<0,01) вищою у 2,76 раза, у серці - на 62,26\% (p<0,05), а в печінці - на 13,51 \% перевищувала показники контрольної групи. 


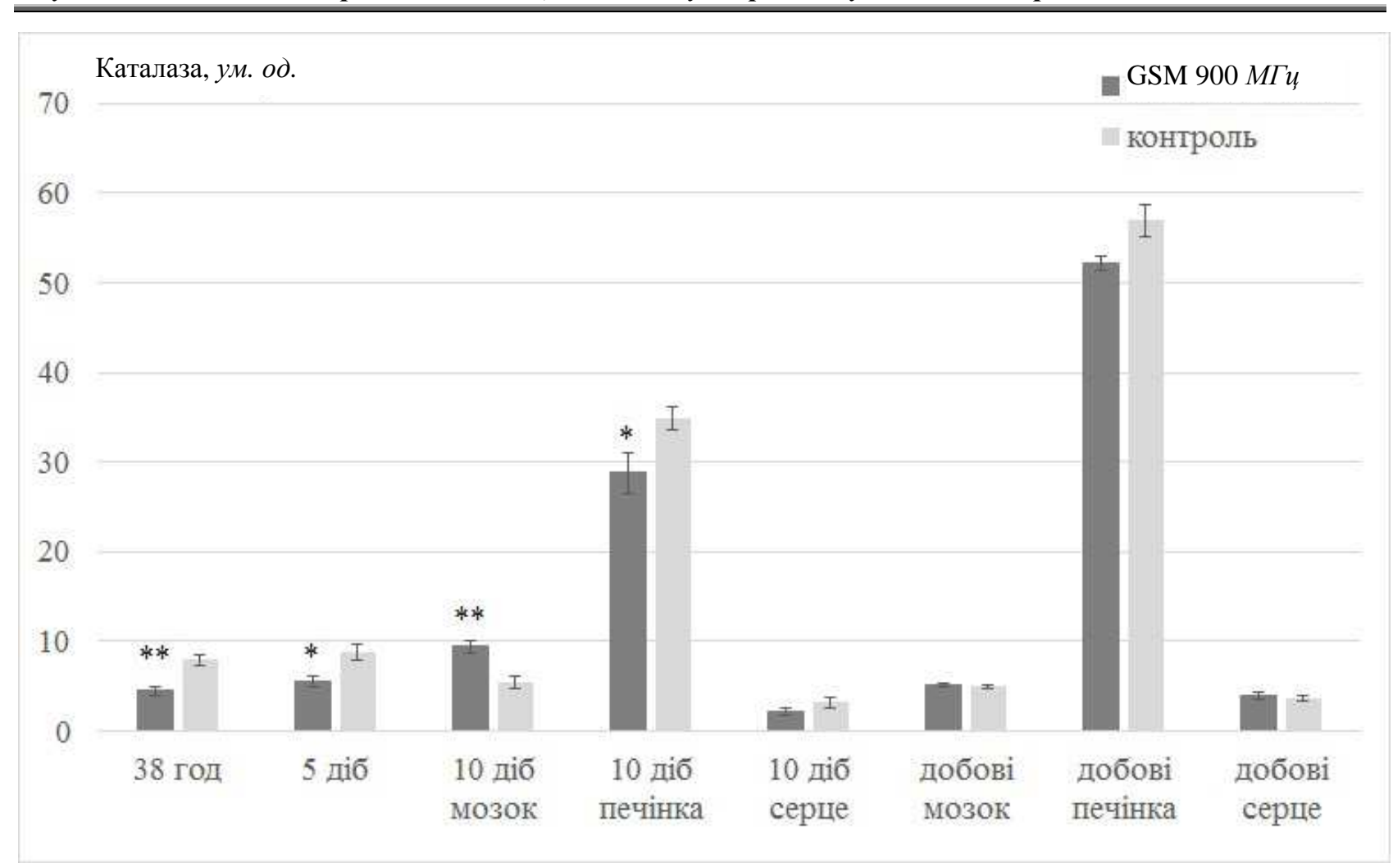

Рис. 2. Вплив опромінення перепелиних яєць мікрохвильовим випромінюванням стандарту GSM 900 MГц на активність каталази в гомогенаті тканин перепелиних ембріонів та добових перепелів: $n=7 ; M \pm m, * p<0,05 ; * * p<0,01$, порівняно з контролем

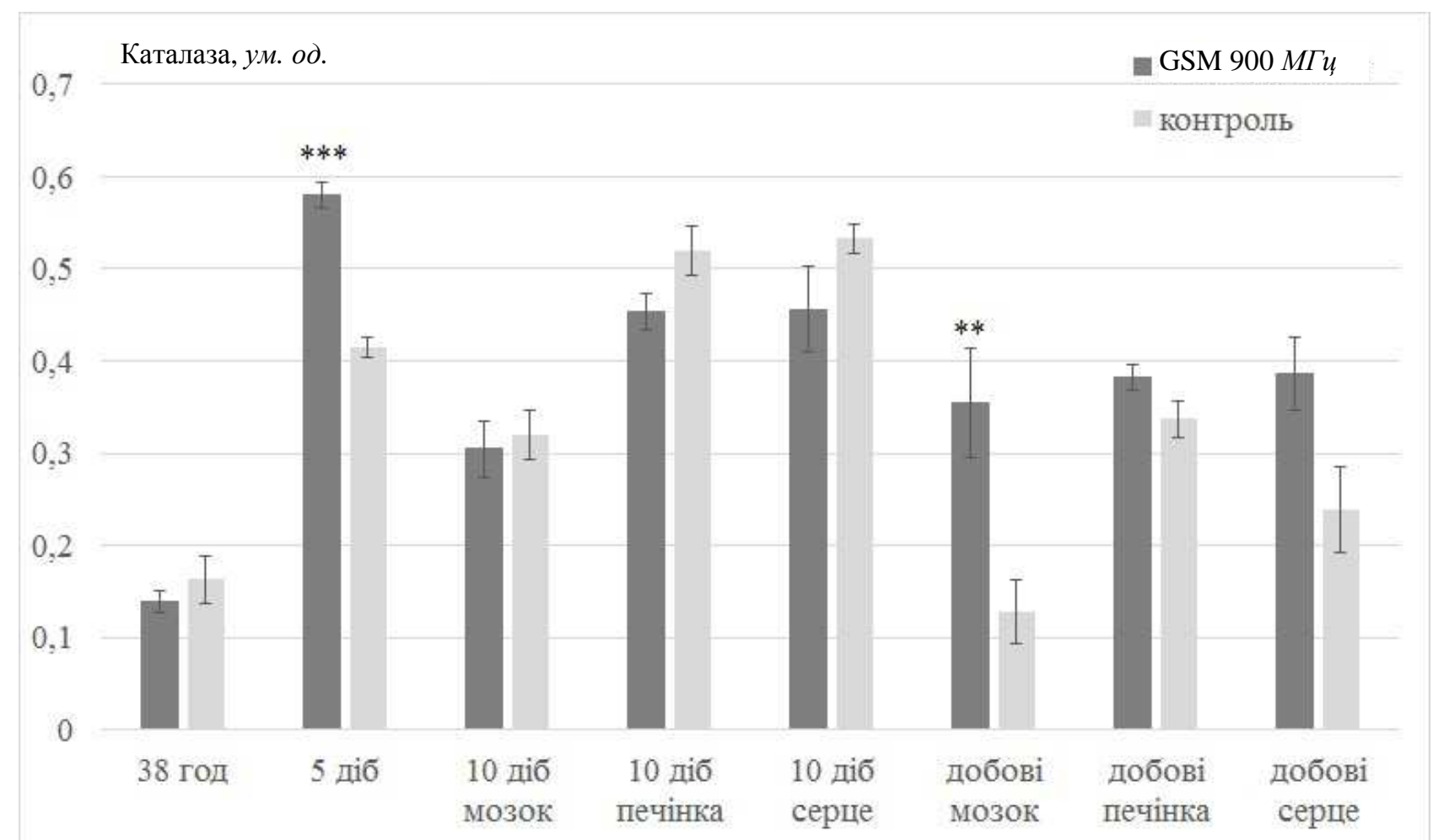

Рис. 3. Вплив опромінення перепелиних яєиь мікрохвильовим випромінюванням стандарту GSM 900 МГи на активність СОД у гомогенаті тканин перепелиних ембріонів та добових перепелів: $n=7 ; M \pm m, * * p<0,01 ; * * * p<0,001$, порівняно з контролем 
У тканинах 38-годинних ембріонів активність церулоплазміну (рис. 4) була вищою на 21,66 \%, порівняно з контролем. У тканинах 5-добових ембріонів дослідної групи активність церулоплазміну була нижчою на 25,19 \% за контрольні показники. У мозку 10-добових ембріонів мікрохвильове випромінювання вірогідно (p<0,001) підвищувало активність церулоплазміну на 91,88 \%, порівняно з контролем. У печінці 10-добових ембріонів активність церулоплазміну за мікрохвильового випромінювання перебувала на рівні контрольної групи. Активність церулоплазміну в серці дослідної групи 10-добових ембріонів була нижчою на $25,2 \%$ ( $<<0,01)$. У добових перепелів вірогідне $(\mathrm{p}<0,05)$ зниження на $21,93 \%$ активності церулоплазміну простежено в печінці птиці дослідної групи, порівняно 3 контролем.

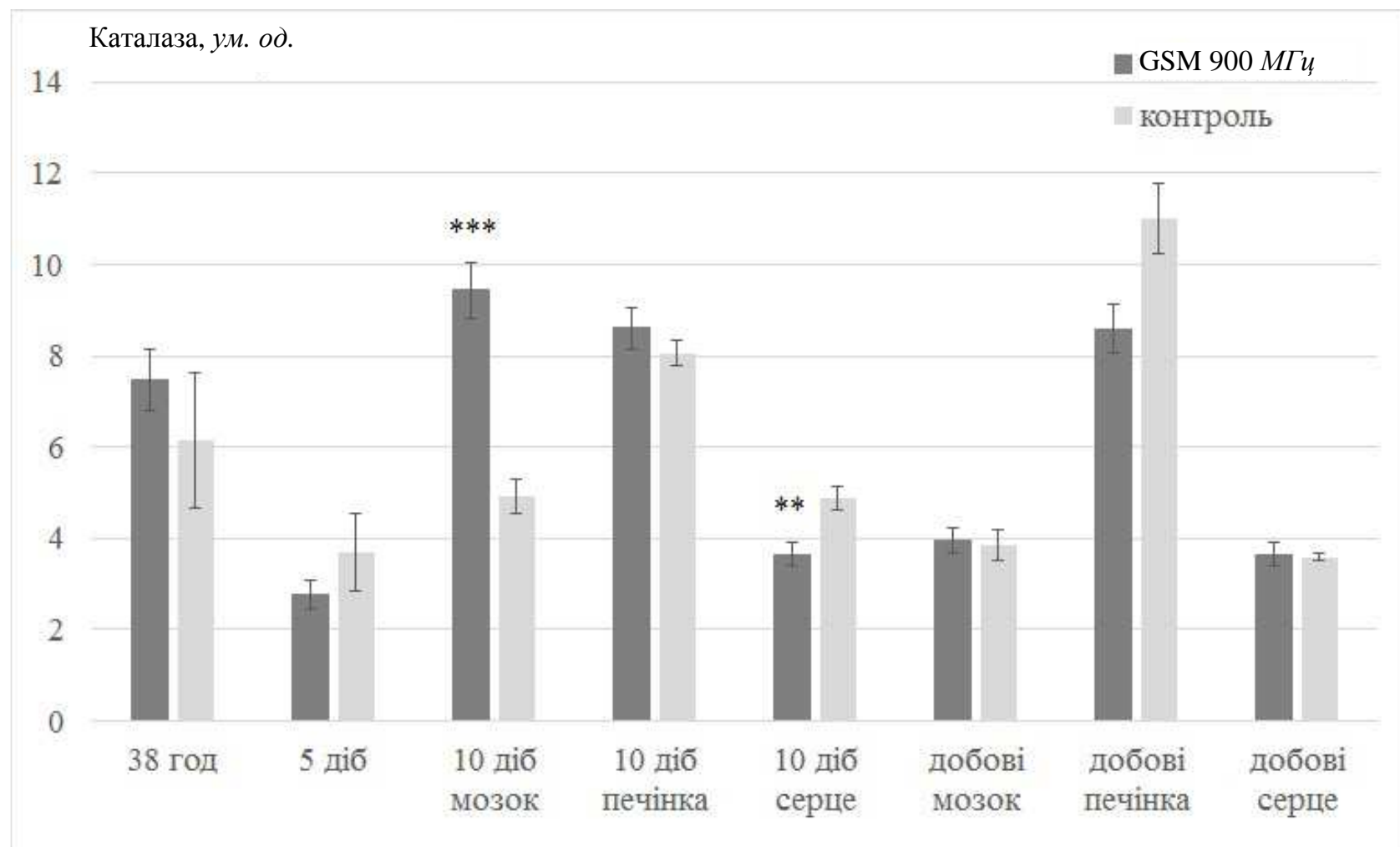

Рис. 4. Вплив опромінення перепелиних яєць мікрохвильовим випромінюванням стандарту GSM $900 \mathrm{M \Gamma u}$ на рівень церулоплазміну в гомогенаті тканин перепелиних ембріонів та добових перепелів: $n=7 ; M \pm m, * * p<0,01 ; * * * p<0,001$, порівняно з контролем

Отримані нами дані засвідчують, що електромагнітне випромінювання радіочастотного діапазону володіє значним оксидативним потенціалом. Значна гіперпродукція АФК призводить до оксидативного стресу в клітинах, спричиняє оксидативне ушкодження ДНК, а отже, може призвести до перетворення клітин у злоякісні [9]. Відомо, що, крім мутагенних ефектів, АФК відіграють роль вторинного месенджера внутрішньоклітинних сигнальних каскадів, які, зі свого боку, можуть викликати онкогенні трансформації [10]. Нами [11] висунуто припущення, що низькоінтенсивне МХВ викликає дисфункцію мітохондрій, що призводить до гіперпродукції супероксиду та NO й АФК-опосередкованого мутагенезу. Також відомо, що оксидативний стрес та канцерогенез пов'язані між собою: наприклад, оксидативний стрес, викликаний матриксною металопротеїназою-1 бере участь як у патогенезі, так і в прогресії раку простати [12]. Крім того, гіперпродукція мітохондріальних АФК на фоні гіпоксії та/або низького рівня глюкози, що приводить до стабілізації клітин підвищеною експресією HIF-2 alpha, також може призводити до злоякісної трансформації [13].

3 іншого боку, на сьогодні зрозуміло, що вільні радикали / АФК $є$ невід'ємною частиною сигнальних каскадів клітини [14]. Так, пероксид водню $є$ вторинним месенджером у трансдукції інсуліну й сигнальних каскадах фактора росту [15]. Також вони беруть участь у біохімічних механізмах окиснення етанолу та в інших метаболічних процесах [16], а також необхідні для ініціювання репарації ран [17]. Крім того, АФК при відносно низьких концентраціях спроможні регулювати перебіг 
запальних процесів за рахунок NF-kB [18]. Тому здатність РЧВ генерувати АФК навіть у незначній кількості може мати вагомі біологічні наслідки.

Раніше нами виявлено, що за тривалого мікрохвильового опромінення in ovo перепелиних ембріонів простежено пригнічення їхнього розвитку $[11 ; 19]$, що супроводжується значною гіперпродукцією супероксидного радикалу й $\mathrm{NO}$, зростанням рівня пероксидного окиснення ліпідів та оксидативним ушкодженням ДНК. Водночас менш тривале опромінення привело до стимуляції ембріонального розвитку $[11 ; 20]$. Установлено позитивні ефекти малих доз опромінення й на молекулярному рівні. Так, короткочасне опромінення РЧВ привело до вірогідного зменшення довжини хвоста ДНК-комет в ембріональних клітинах, порівняно 3 неопроміненим контролем, що вказує на активацію механізмів зменшення розривів ДНК. «Корисні» наслідки опромінення можна пояснити ефектом гормезису [21]. Проте можливо, що «корисні» ефекти опромінення пояснюються сигнальною дією вільних радикалів, які проявляються при рівнях, нижчих за ті, що можуть викликати ушкодження. Однак до будь-якого позитивного ефекту впливу зовнішніх факторів потрібно ставитися з обережністю й, за можливості, мінімізувати їх, принаймні, до точної оцінки віддалених наслідків.

Загалом, наші дані свідчать про чіткий попереджувальний сигнал негативної дії низькоінтенсивного РЧВ для здоров'я людини, що може бути викликано як прямим оксидативним ушкодженням, так і внаслідок порушення сигнальних каскадів клітини.

Висновки й перспективи подальших досліджень. Отримані нами дані засвідчують виражені оксидативні ефекти низькоінтенсивного електромагнітного випромінювання стандарту GSM 900 МГц на ембріональні та клітини добових перепелів. Надмалі інтенсивності EMB, за яких виявлялися виражені ефекти, засвідчують необхідність нових підходів при оцінці безпечних рівнів ЕМВ радіочастотного діапазону для біологічних систем й організму людини зокрема.

\section{Джкерела та література}

1. Maes W. [Stress caused by electromagnetic fields and radiation] / W. Maes. - Neubeuern, Germany : IBN, 2005. - P. 602

2. [Elektronik resourse]. - Mode of access : http://www.itu.int/en/itu-d/statistics/documents/facts/ictfacts Figures2015.pdf

3. Yakymenko I. Long-term exposure to microwave radiation provokes cancer growth: evidences from radars and mobile communication systems / I. Yakymenko, E. Sidorik, S. Kyrylenko,V. Chekhun // Exp Oncol. 2011. - V. 33. - P. 62-70.

4. Yakymenko I. Low intensity radiofrequency radiation: a new oxidant for living cells / I. Yakymenko, E. Sidorik, D. Henshel, S. Kyrylenko // Oxid Antioxid Med Sci. - 2014. - V. 3. - P. 1-3.

5. Draper H. H. Malondialdehyde determination as index of lipid peroxidation / H. H. Draper, M. Hadley // Methods in enzymology. - 1990. - V. 186. - P. 421-31.

6. Королюк М. А. Метод определения активности каталазы / М. А. Королюк, Л. И. Иванова, И. Г. Майорова, В. Е. Токарев // Лаб. дело. - 1988. - V. - Р. 16-19.

7. Чавари С. Роль супероксиддисмутазы в окислительных процессах клетки и метод определения ее в биологических материалах / С. Чавари, И. Чаба, Й. Секуй // Лаб. дело. - 1985. - V 39. - Р. 678-681.

8. Тен Э. В. Экспресс-метод определения содерæания церулоплазмина в сыворотке крови / Э. В. Тен // Лаб. дело. - 1981. - V. - Р. 334-335.

9. Valko M. Free radicals and antioxidants in normal physiological functions and human disease / M. Valko, D. Leibfritz, J. Moncol, M. T. Cronin, M. Mazur, J. Telser // The international journal of biochemistry \& cell biology. - 2007. - V. 39. - P. 44-84.

10. Valko M. Free radicals, metals and antioxidants in oxidative stress-induced cancer / M. Valko, C. J. Rhodes, J. Moncol, M. Izakovic, M. Mazur // Chemico-biological interactions. - 2006. - V. 160. - P. 1-40.

11. Burlaka A. Overproduction of free radical species in embryonal cells exposed to low intensity radiofrequency radiation / A. Burlaka, O. Tsybulin, E. Sidorik, S. Lukin, V. Polishuk, S. Tsehmistrenko,I. Yakymenko // Exp Oncol. - 2013. - V. 35. - P. 219-225.

12. Nguyen H. L. Oxidative stress and prostate cancer progression are elicited by membrane-type 1 matrix metalloproteinase / H. L. Nguyen, S. Zucker, K. Zarrabi, P. Kadam, C. Schmidt, J. Cao // Mol Cancer Res. 2011. - V. 9. - P. 1305-1318.

13. Ralph S. J. The causes of cancer revisited: «Mitochondrial malignancy» and ROS-induced oncogenic transformation - Why mitochondria are targets for cancer therapy / S. J. Ralph, S. Rodríguez-Enríquez, J. Neuzil et al. // Molecular aspects of medicine. - 2010. - V. 31. - P. 145-170.

14. Forman H. J. An overview of mechanisms of redox signaling / H. J. Forman, F. Ursini,M. Maiorino // Journal of molecular and cellular cardiology. - 2014. - V. 73. - P. 2-9. 
15. Sies H. Role of metabolic $\mathrm{H} 2 \mathrm{O} 2$ generation: redox signaling and oxidative stress / H. Sies // The Journal of biological chemistry. - 2014. - V. 289. - P. 8735-8741.

16. Oshino N. Optical measurement of the catalase-hydrogen peroxide intermediate (Compound I) in the liver of anaesthetized rats and its implication to hydrogen peroxide production in situ / N. Oshino, D. Jamieson, T. Sugano, B. Chance // The Biochemical journal. - 1975. - V. 146. - P. 67-77.

17. Enyedi B. H2O2: a chemoattractant? / B. Enyedi, P. Niethammer // Methods in enzymology. - 2013. - V. 528. P. 237-255.

18. Hayden M. S. NF-kappaB in immunobiology / M. S. Hayden,S. Ghosh // Cell research. - 2011. - V. 21. P. 223-244.

19. Tsybulin O. GSM $900 \mathrm{MHz}$ microwave radiation affects embryo development of Japanese quails / O. Tsybulin, E. Sidorik, S. Kyrylenko et al. // Electromagnetic biology and medicine. - 2012. - V. 31. - P. 75-86.

20. Tsybulin O. GSM $900 \mathrm{MHz}$ cellular phone radiation can either stimulate or depress early embryogenesis in Japanese quails depending on the duration of exposure / O. Tsybulin, E. Sidorik, O. Brieieva et al. // International journal of radiation biology. - 2013. - V. 89. - P. 756-763.

21. Calabrese E. J. Hormesis: why it is important to toxicology and toxicologists / E. J. Calabrese // Environ Toxicol Chem. - 2008. - V. 27. - P. 1451-1474.

Цыбулин Александр. Влияние микроволнового излучения на состояние антиоксидантной системы перепелиных эмбрионов и суточного молодняка. Длительное воздействие на человека низкоинтенсивного радиочастотного электромагнитного излучения приводит к достоверному увеличению риска возникновения раковых опухолей. Механизмы таких эффектов не ясны, но во многих работах указывается на признаки окислительного стресса в живых клетках под воздействием радиочастотного электромагнитного излучения. Целью нашего исследования было изучение влияния микроволнового излучения на состояние антиоксидантной системы в тканях перепелиных эмбрионов и суточного молодняка. Эмбрионы перепела японского подвергались in ovo низкоинтенсивному микроволновому облучению GSM 900 МГц (14 мкВт/см²) в течение 158-456 ч (48 c - ON, 12 c - OFF) до и на начальных этапах развития. Было продемонстрировано достоверное окислительное воздействие микроволнового излучения на модели перепелиных эмбрионов. Эффект проявляется в повышенном уровне перекисного окисления липидов и снижение активности ключевых ферментов антиоксидантной системы.

Ключевые слова: микроволновое излучение, мобильный телефон, эмбриогенез, окислительный стресс, антиоксиданты.

Tsybulin Olexandr. Influence of Microwave Radiation on Antioxidant System in the Tissues of Embryos and Daily Quail. Long-term exposure of humans to low intensity radiofrequency electromagnetic radiation (RF-EMR) leads to a statistically significant increase in tumor incidence. Mechanisms of such the effects are unclear, but features of oxidative stress in living cells under RF-EMR exposure were previously reported. The aim of our study was to investigate the effect of microwave radiation on the state of the antioxidant system in the tissues of embryo and daily quail. Embryos of Japanese quails were exposed in ovo to extremely low intensity RF-EMR of GSM $900 \mathrm{MHz}$ $\left(14 \mu \mathrm{W} / \mathrm{cm}^{2}\right)$ during $158-456 \mathrm{~h}$ discontinuously (48 c - ON, $12 \mathrm{c}-\mathrm{OFF}$ ) before and in the initial stages of development. Significant oxidative effect of microwave radiation on the model of quail embryos was demonstrated. The effect was manifested in increased level of lipid peroxidation and decreased activity of key enzymes of antioxidant system.

Key words: microwave radiation, mobile phone, embryogenesis, oxidative stress, antioxidants.

Стаття надійшла до редколегії 03.09.2016 р.

УДК 616.155.194.8-056.5: 616-06: 618.11-008.64: 618.17

Аліна Литвиненко,
Марія Ступчук,
Орест Блашків,
Тетяна Вознесенська

\section{Морфофункціональний стан жіночої репродуктивної системи за умов застосування наночастинок срібла}

За умов одно-, п'яти- та десятикратного внутрішньовенного введення наночастинок срібла (2 мг/кг та 4 мг/кг) оцінювали мейотичне дозрівання ооцитів, а також за умов десятикратного внутрішньовенного введення наночастинок срібла (2 мг/кг та 4 мг/кг) - пре- й постімплантаційну смертність ембріонів у мишей.

() Литвиненко А., Ступчук М., Блашків О., Вознесенська Т., 2016 